\title{
Retraction Note: The experimental research on properties, structures and applies polymer sulfur composites as the industrial waste material in the industry objects
}

\author{
Mariusz Książek
}

Accepted: 22 December 2021 / Published online: 25 January 2022

(C) RILEM 2022

\section{Retraction note: Materials and Structures https://doi.org/10.1617/s11527-014-0397-1}

The Editor-in-Chief and Publisher have retracted this article because the validity of the content of this article cannot be verified. An investigation by the Publisher found evidence suggestive of attempts to subvert the peer review and publication system. In addition, there is significant overlap with three previously published articles [1-3]. The author has not responded to correspondence from the publisher about this retraction.

\section{References}

1. Książek, M (2014) The experimental investigations of propriety and applies in the building special coating - Sulfur polymer composite as the industrial waste material. Compos. B. Eng. 58: 378-385 (March). Retracted article

2. Książek, M (2014) The evaluate tendencies of corrosion process for reinforcing steel when covered with special polymer sulfur coating. Eng. Fail. Anal. 39: 1-11 (April). Retracted article

3. Książek, M (2013) The intensity of corrosion processes influenced by tensile stress for reinforcing steel covered with sulphur polymer composite applied as industrial waste material. Compos. B. Eng. 45(1): 1126-1132 (February). Retracted article

Publisher's Note Springer Nature remains neutral with regard to jurisdictional claims in published maps and institutional affiliations.
The original article can be found online at https:// doi.org/10.1617/s11527-014-0397-1.

M. Książek ( $\bowtie)$

Division of Building Materials, Timber and Monumental Heritage Structures, Institute of Building Engineering, Wrocław University of Technology, pl. Grunwaldzki 11, 50-377 Wrocław, Poland e-mail: ksiazekmariusz@wp.pl 